\title{
A likviditásnyújtás kereskedési stratégiájának hozamvizsgálata a magyar részvénypiacon
}

A tanulmányban kétféle megközelítéssel vizsgáljuk azt, hogy lehetett-e a likviditásnyújtás stratégiáját alkalmazva szignifikánsan pozitív hozamot elérni a magyar részvénypiacon. Az első esetben portfóliókat képezünk, a másodikban speciálisan a likviditásnyújtásra vonatkozó stratégiát vizsgálunk. Mindkét megközelítés lényege, hogy a rövid távon magas hozamú részvényeket eladni, a nagy veszteseket pedig megvenni érdemes. A likviditásnyújtás mindkét értelmezésével a nemzetközi irodalom alapján várt eredményt kapjuk. Likviditásszükében csak magas hozam mellett valósul meg likviditásnyújtás, s ez még a kisebb magyar tőzsdén is statisztikailag szignifikáns eredményt ad.

Journal of Economic Literature (JEL) kód: G11, G12.

\section{Bevezetés}

Az átlaghoz való visszatérés az egyik legismertebb összefüggés az amerikai részvényhozamokkal kapcsolatban (például Lehmann [1990], Nagel [2012]). Ez azt jelenti, hogy egy hipotetikus kereskedési stratégia, amely megveszi a rövid távon vesztes részvényeket és eladja a rövid távon nyertes részvényeket, szignifikánsan pozitív hozamot hoz. A legelterjedtebb magyarázat erre az összefüggésre, hogy ez a hozam azért marad fenn, mert ez a nyeresége azoknak a befektetőknek, akik hajlandók likviditást nyújtani (Nagel [2012]). Emiatt az ilyen típusú stratégiát nevezhetjük likviditásnyújtó stratégiának. Bár ennek legnagyobb alkalmazói professzionális befektetők, jellemzően kisebb befektetők is követik ezt a stratégiát, s így likviditást nyújtanak a nemzetközi piacokon is (Hendershott és szerzőtársai [2011], Kaniel és szerzőtársai [2007]).

Tanulmányunkban azt vizsgáljuk meg a magyar tőkepiacon, hogy a nemzetközi irodalom mennyire használható a hozamok rövid távú visszafordulásával kapcsolatban, az erre adott likviditási modellek mennyire müködnek jól a magyar részvénypiacon. Ehhez két különböző megközelítést is használunk. Az első esetben portfóliókat

Neszveda Gábor, Budapesti Corvinus Egyetem (e-mail: gabor.neszveda@uni-corvinus.hu). Vágó Ákos, Budapesti Corvinus Egyetem (e-mail: vagoakos98@gmail.com). 
képezünk, a legjobban teljesítő részvényeket tartalmazó portfóliót eladjuk, míg a legrosszabbul teljesítő részvényeket tartalmazó portfóliót megvesszük minden hónapban. Végül az így képzett hipotetikus kereskedési stratégia várható hozamát vizsgáljuk. A második esetben egy hasonló elgondolásra épülő kereskedési stratégiát tesztelünk, követve Nagel [2012] módszertanát. Ekkor minden hónapban annak függvényében fektetünk be egy részvénybe, hogy az előző hónapban mennyire tért el a piaci átlagtól. Itt is azt várjuk, hogy a hozamok visszatérnek az átlaghoz. Mindkét esetben havonta újrasúlyozzuk portfóliónkat, annak ellenére, hogy a likviditásnyújtás célja, hogy a befektetők minél gyorsabban zárják le a pozíciókat, és ezáltal a tartási idő gyakran rövidebb egy napnál, de jellemzően nem hosszabb néhány napnál. A legtöbb nemzetközi elemzés azonban havi újrasúlyozást használ (például HameedMian [2015]), és több eredmény is azt mutatja, hogy a keresett hatás még egy hónapos időtávon vagy akár ezen túl is megfigyelhetö (például Chan [2003]). Ezért követve a szakirodalmat, mi is havi adatokon tesztelünk.

A likviditásnyújtással kapcsolatos nemzetközi irodalom alapján azt várjuk, hogy ezek a kereskedési stratégiák lényegesen magasabb hozamot hoznak peszszimista, kiszámíthatatlanabb gazdasági környezetben, mivel ekkor a likviditási költségek is lényegesen magasabbak a likviditásszüke és a volatilisebb környezet miatt (például Nagel [2012], Hameed-Mian [2015]). Tehát a két fő hipotézisünk, amit vizsgálunk, hogy létezik-e a magyar részvénypiacon is a hozamok átlaghoz való visszatérése, illetve az erre épülő kereskedési stratégiák magasabb hozamot nyújtanak-e pesszimista, kiszámíthatatlanabb időszakokban a likviditásnyújtás elméletével összhangban.

Az eredményeink alapján mindkét megközelítésben pozitív a kereskedési stratégiánk hozama, de statisztikailag nem szignifikáns. Ennek az is lehet az oka, hogy a mintaelemszám viszonylag alacsony. Ellenben, ha felbontjuk a teljes idöszakot pesszimista és optimista időszakokra vagy bizonytalanabb és kiszámíthatóbb időszakokra, akkor már azt kapjuk, hogy nemcsak magas pozitív hozamot érnek el ezek a stratégiák, de minden szokásos szignifikanciaszint mellett statisztikailag is szignifikánsak a hozamok. Ez azt mutatja, hogy a likviditásnyújtás szerinti megközelítésnek még a kisebb magyar piacon is erös a várható hozamokra vonatkozó magyarázóereje.

A likviditás szerepét számos különböző megközelítésben vizsgálták már Magyarországra vonatkozóan is. Ha egy pozíciót csak magas költségek mellett lehet majd felszámolni, azt a piac beépíti a jelenlegi árba (Váradi [2012]). Így az alacsony likviditás miatti kockázat normál körülmények között az elvárt hozamban is megjelenik (Csávás-Erhart [2005]). A likviditást elősegítendő, sokszor megjelennek árjegyzők is, amelyek tovább tudják erősíteni a piac müködését (Hevér [2017]). Ezzel szemben ez a tanulmány kifejezetten a hozamok elörejelezhetősége szempontjából vizsgálja a kérdést a magyar részvénypiacon, és ezen belül is arra kíván választ kapni, hogy létezik-e a hozamokban az átlaghoz való visszatérés, és ez valóban függ-e a likviditásszükétől, ahogy azt a nemzetközi irodalom alapján várni lehet. Ezen belül pedig további kérdés, hogy az adatok alapján mely mutató ragadja meg legjobban a pesszimista hangulatot. Három mutatót összehasonlítva (GKI magyar 
konjunktúraindex, euróövezeti OECD-hangulatindex és az amerikai VIX) az az eredmény rajzolódik ki, hogy a külföldi likviditásszűkét jelző mutatók jobban megragadják a várható hozamokat a magyar indexhez képest.

\section{Adatok}

Elöször letöltjük a magyar piac minden részvényének havi adatát a Thomson Reuters Refinitiv-adatbázisából. A nem amerikai részvénypiacok esetében ezt az adatbázist használják a leggyakrabban a kutatásokban (például Annaert és szerzőtársai [2013], Cheon-Lee [2017]). A Budapesti Értéktőzsde 1990 júniusában nyílt meg újra, ezért az adatokat ettől a hónaptól kezdve 2019 októberéig töltjük le. A letöltött adattípusok a részvények árfolyamai, a forgalomban lévő részvények száma, az adott részvény kereskedésének volumene és a teljeshozam-index. A már kivezetett részvények adatait is figyelembe vesszük, hogy elkerüljük az esetleges túlélési torzítást (Shumway [1997]).

A letöltött adatokat kiegészítjük az említett három, befektetői várakozásokat jellemző mutatóval, mert azt is szeretnénk vizsgálni, hogy előre jelzik-e az ilyen típusú mutatók a kétféle stratégia várható hozamát.

Az első indikátor a GKI konjunktúraindexe, amely a magyarországi gazdasági várakozásokat számszerűsíti. Az index a GKI két másik mutatójának súlyozott átlaga, az egyik ilyen mutató a GKI üzleti bizalom, amely a magyar gazdaságirányítással foglalkozó szervek és a nagyvállalatok várakozásait számszerüsíti, ennek a mutatónak a súlya 0,74 . A másik mutató, a GKI fogyasztói, lakossági várakozásokat számszerüsítő fogyasztói bizalmi indexének a súlya 0,26 . Tehát a GKI konjunktúraindex a magyar gazdasági élet minden szereplőjének várakozását figyelembe veszi, ezért ítéltük a mutatót relevánsnak. A tőkepiacokon valószínűleg a nagyvállalatok és a gazdaságirányítással foglalkozó szervek várakozásai a lakossági várakozásoknál nagyobb hatásúak, ezért a súlyozás is megfelelőnek tűnik. A GKI a mutató havi értékét az adott hónap második felében teszi közzé, így a mutató a stratégia következő havi hozamának elörejelzésére már használható. A mutató értéke csak 1996-tól érhetö el, így a kutatásnak ezt a részét legjobb esetben is csak ettől az évtől tudjuk elkezdeni. Tehát a tanulmányhoz használt adatbázishoz hozzáadjuk a GKI honlapjáról ${ }^{1}$ letöltött konjunktúraindex-értéket 1996-tól 2019 októberéig.

Magyarország tőzsdéjén a külföldi befektetők aránya nagyon magas, a BÉT honlapja ${ }^{2}$ szerint a tőzsde részvénykapitalizációjának és -forgalmának 70-80 százalékát külföldiek birtokolják. A külföldi befektetők pesszimista gazdasági várakozások esetén igen gyakran vonják ki tőkéjüket egy másik országból, és inkább saját országukban keresnek új befektetési lehetőségeket, vagy az egész világon biztonságosnak tekintett eszközökbe fektetnek. Ha az arányuk jelentős, akkor az esetleges negatív

\footnotetext{
${ }^{1}$ GKI honlap: https://www.gki.hu/language/hu/2019/12/20/haromeves-melypontjan-zarta-az-eveta-gki-konjunkturaindexe/ (utolsó letöltés dátuma: 2020. január 10.).

${ }^{2}$ BÉT honlap: https://www.bet.hu/Kibocsatok/vallalati-tudastar/A-tozsdei-jelenlet-elonyei.
} 
gazdasági kilátások esetében nagymértékű likviditáskivonás érheti az adott piacot, így a piacon maradó likviditás nagymértékben felértékelődhet, s a likviditásnyújtás hozama igen magas lehet. Emiatt a másik két mutató a külföldi befektetői várakozásokat jellemzi. A külföldre vonatkozó mutatók kiválasztásánál felmerülhet, hogy az alapján válasszunk, hogy mely országok befektetői tevékenykednek nagy számban vagy nagy összegekkel a magyar tőzsdén. Erről azonban igen kevés adatot találunk, és hosszú távon ezek az adatok valószínűleg igen változékonyak, ezért inkább egyéb, főként makrogazdasági indokok alapján választjuk ki a mutatókat.

A világon elterjedt az OECD fogyasztói várakozásokat jellemző mutatója, a Consumer Confidence Index (CCI). A mutató nevének magyar fordítása szintén fogyasztói bizalmi index, azonban a mutató nem azonos a GKI megegyező nevü mutatójával. Ez is a fogyasztók gazdasági növekedéssel kapcsolatos várakozásait számszerüsíti. A mutató előre meghatározott küszöbértékkel rendelkezik, a 100 feletti érték optimista, a 100 alatti érték pesszimista várakozásokat jelent, a 100as érték pedig megfeleltethető egy semleges állapotnak. Az OECD meghatározása szerint a mutató hosszú távú átlaga éppen 100, ez a gazdasági ciklusok elméletével van összhangban. Az indikátor használata az Egyesült Államokból indult, de az OECD honlapján ma már számos országra, országcsoportra megtalálhatók az értékei. A mutató értékei egy, maximum két héttel az adott hónap vége után érhetőek el, így közvetlenül előrejelzésre ezek nem használhatók. A gyakorlatban például makrogazdasági hírek alapján következtethetünk a mutatók alakulására és ezzel az adott havi befektetöi hangulatra.

A különböző CCI-k közül az euróövezetre vonatkozó mutatót használjuk. Magyarország az Európai Unió tagja, emiatt pénzügyi-gazdasági összekapcsoltsága az EU más tagjaival igen jelentős, valószínü, hogy a BÉT-en tevékenykedő külföldi befektetők jelentős része származik EU-tagállamból. Az euróövezeti tagok jellemzően az EU erősebb gazdaságai, ezekben az országokban több a befektetési szolgáltatást nyújtó pénzügyi intézmény, illetve a tőkeerős, pénzét befektetni kívánó gazdasági szereplő, ezért az EU-tagállamokból érkező befektetők között valószínüleg túlsúlyban vannak az euróövezetböl származó befektetők. Tehát mindenképpen érdemes az euróövezet gazdasági várakozásaival is összevetnünk a stratégia hozamait, ezért az OECD honlapjáról ${ }^{3}$ letöltjük az euróövezetre vonatkozó CCIadatokat, és hozzáadjuk őket az adatbázisunkhoz.

Európán kívülről az Egyesült Államok gazdasági várakozásaival fogjuk összevetni a stratégia hozamait. Az Egyesült Államok hatása a világgazdaságban igen jelentős, könnyen lehet, hogy a magyar részvényárfolyamokra is nagy hatással vannak az ország gazdasági várakozásai. Továbbá a világ legjelentősebb intézményi befektetőinek nagy része amerikai, e befektetők egy része valószínüleg a magyar részvénypiacon is jelen van, ez is indokolja, hogy az Egyesült Államokra vonatkozó mutatót is vizsgálunk. E mutatónk a Nagel [2012] által is használt VIX index, amely az S\&P500opciókba árazott volatilitást méri, és az Egyesült Államok első számú befektetői

\footnotetext{
${ }^{3}$ OECD CCI-adatbázis: https://data.oecd.org/leadind/consumer-confidence-index-cci.htm (utolsó letöltés dátuma: 2020. január 10.).
} 
félelmet és várakozásokat jellemző mutatójának tartják. Ez a mutató eltér abban az eddigiektől, hogy közvetlenül a tőzsdén tapasztalható várakozásokat, félelmet számszerüsíti. A VIX index egy volatilitási index, így százalékként is értelmezhetö. A VIX index sokak szerint az egész világon befolyásolja a pénzügyi eszközök hozamait, ezért arra számítunk, hogy a mutató a BÉT esetében is jó elörejelző képességü. A VIX indexre vonatkozó havi adatokat letölthetjük például a Yahoo Finance-röl, ${ }^{4}$ ezeket az adatokat is hozzáadjuk adatbázisunkhoz. A VIX indexszel kereskedhetünk is, így az adott havi érték ebben az esetben rendelkezésre áll a hónap végén, elörejelzésre használható. Ezzel az adatbázisunk elkészült.

Ezután további mutatók értékeit fogjuk kiszámolni. Meghatározzuk az egymást követő havi hozamokat minden részvényre. Egy adott havi hozamot úgy kapunk, hogy a következö hónap teljeshozam-indexét elosztjuk az adott hónap teljeshozam-indexével, és az így kapott hányadosból kivonunk 1-et. Mivel 1990 júniusától 2019 októberéig vannak adataink, 1990 júniusától 2019 szeptemberéig fognak rendelkezésünkre állni a hozamok, hiszen az adott havi hozam kiszámításához szükség van a következö havi teljeshozam-indexre, viszont ez 2019 novemberére már nem áll rendelkezésre, így a 2019. októberi hozamot már nem tudjuk kiszámítani. Szükségünk lesz még egy mutatóra, ez a részvényforgalmi (turnover) illikviditási mutató, amely az adott havi kereskedett részvénymennyiség, illetve a piacon lévő részvények számának hányadosa.

Így már minden adattal rendelkezünk, amit használni szeretnénk, így kezdetben 26507 megfigyelésünk van, de az adatbázis még hiányos lehet, illetve az extrém értékeket is kezelnünk kell, hogy ezek ne torzítsák a tesztek eredményeit. Az adatok tisztítását Mérő és szerzőtársai [2019] alapján végezzük el. Töröljük azokat a megfigyeléseket, amelyeknél a hozam, a részvényforgalmi illikviditási mutató vagy valamelyik fogyasztói, befektetői várakozásokat jellemző mutató hiányzik. A hozamok kapcsán elhagyjuk az extrém értékeket, a 300 százalék feletti havi hozamokat, ezzel csökkentve a potenciális adathibák okozta zajt (Nartea és szerzötársai [2017]). Ezután töröljük minden hónap leginkább illikvid részvényeit, vagyis azokat a részvényeket, melyek az adott havi részvényforgalmi illikviditási értékek alsó 5 százalékához tartoznak. Ezt azért tesszük meg, mert ezen szélsőségesen illikvid részvények forgalma gyakran nulla az adott hónapban, ami megkérdőjelezi az adat jelentőségét és értelmét. Különösen problémás lehet az, ha adataink között sok ilyen extrém illikvid részvény van. Ennél nagyobb számban azért nem töröljük a részvényeket, hogy ne veszítsünk túl sok adatot. A magyar tőzsde alapvetően is kevés megfigyeléssel rendelkezik, illetve a vizsgált befektetési stratégia éppen az esetleges likviditásszűkét igyekszik kihasználni, így ebben az esetben dolgozhatunk egy enyhébb korláttal. Ezután töröljük azokat a hónapokat, amelyekben nincs legalább 20 megfigyelésünk. Erre azért van szükség, mert a statisztikai tesztek értelmezéséhez szükséges egy minimális megfigyelésszám egy hónapban. Így végül egy olyan adatbázist kapunk, amelyet használva 1997 februárjától 2019 januárjáig tudjuk tesztelni a stratégia hozamait. Ez

\footnotetext{
${ }^{4}$ Yahoo Finance VIX index: https://finance.yahoo.com/quote/ZM/history?p=ZM (utolsó letöltés dátuma: 2020. január 10.).
} 
alapján nem probléma, hogy a GKI konjunktúraindex értékeit csak 1996-tól érjük el. Összesen 8858 megfigyelésünk marad, ez átlagosan kicsivel több, mint 35 megfigyelést jelent havonta. Ez a nemzetközi elemzésekhez képest egy kicsi szám, de ha még így is - a kis elemszám és a zajos adatok ellenére is - szignifikáns összefüggéseket találunk, az csak megerősíti az eredményeket.

\section{A portfólióképzésen alapuló stratégia hozamainak tesztelése}

Az első megközelítésben portfóliókat képzünk a Fama-French [1992]-féle egyváltozós sorba rendezés alapján. Mivel a rövid távon vesztes részvényeket vesszük meg, és a rövid távon nyertes részvényeket adjuk el, az adott havi portfóliónkat az előző havi hozamok alapján alakítjuk ki, az előző havi hozam lesz az a változó, amely alapján az egyváltozós sorba rendezést végezzük. Konkrétan 1997 januárjától 2018 decemberéig minden hónapban az előző havi hozamok alapján rendezzük sorba a részvényeket, így 1997 februárjától 2019 januárjáig tudjuk meghatározni a portfóliónk összetételét, ezért a likviditásnyújtás hozamait is erre az időszakra tudjuk tesztelni. Mivel havi hozamokat vizsgálunk, 264 megfigyelésünk lesz.

A megfigyeléseinket többféleképpen oszthatjuk részekre, emiatt a megvásárolt és az eladott portfólió is változhat. Elöször a Fama-French-féle megoldást követjük, az adatainkat három részre bontjuk minden hónapban, és a legalacsonyabb 30 százalék az alsó tercilisbe, a legmagasabb 30 százalék a felső tercilisbe, a többi részvény pedig a középső tercilisbe kerül. Ezek ugyan a szó szokásos értelmében nem tercilisek, de a könnyebbség kedvéért mi mégis így nevezzük öket. Ezután minden hónapra meghatározzuk a részportfóliók egyenlően súlyozott hozamát. Az így létrehozott portfóliókat az árfolyamváltozások miatt minden hónapban újra kell súlyozni, viszont a stratégia várhatóan jobb hozamai miatt ezt megéri megtennünk, illetve a stratégiának köszönhetö többletlikviditás a kisebb részvények piacán jelentős mértékben segítheti a kereskedés folytonosságát.

A likviditásnyújtás meghatározása szerint az 1. tercilisbe tartozó részvényeket veszszük meg, és a 3. tercilisben lévő részvényeket adjuk el. Ez alapján minden hónapra meghatározzuk az 1. portfólió és a 3. portfólió hozamának különbségét. Ez a különbség lesz a likviditásnyújtás havi hozama, mert az alsó 30 százalék átlaghozamából vonjuk ki a felső 30 százalék átlaghozamát, és mi éppen az alsó 30 százalékot veszszük meg, és a felső 30 százalékot adjuk el. Ezután az egyváltozós sorba rendezésnél megszokott módon teszteljük, hogy a részportfóliók hozama szignifikánsan eltér-e 0-tól, majd pedig rátérünk a stratégia havi hozamának tesztelésére. A teszteket a Newey-West [1987]-féle korrigált $t$-statisztikával fogjuk elvégezni, amely autokorrelációval és heteroszkedaszticitással korrigált kovarianciamátrixszal dolgozik. A pénzügyekben sokáig tartotta magát a hatékony piacok elméletének azon változata (Fama [1991]), amely szerint az egymást követő hozamok időben függetlenek, nincs autokorreláció az egymást követő hozamok között. Ma már viszont az a nézet jellemző, hogy az egymást követő hozamok időben nem függetlenek (például Cochrane [1999]), van autokorreláció. Továbbá részvényhozamok esetében előfordulhat 
heteroszkedaszticitás, a hozamok szórása gyakran nem állandó időben, például válságok időszakában a volatilitás általában megnő. Ezért a teszteket autokorrelációval és heteroszkedaszticitással korrigálva érdemes elvégeznünk.

A részportfóliók és a likviditásnyújtás hozamaira vonatkozó teszteket a teljes, vagyis az 1997 februárja és 2019 januárja közötti időszakra végezzük el. A tesztek nullhipotézise az, hogy az adott hozam 0, és a statisztikában leggyakrabban használt 5 százalékos szignifikanciaszinten fogunk dönteni. Minden teszt esetében megadjuk a várható hozamot, ami a $t$-teszt tulajdonságai szerint éppen a havi hozamok átlaga lesz, ez egy befektetési stratégia esetében rendkívül fontos. Továbbá megadjuk a $t$-értéket is, hogy dönteni tudjunk a nullhipotézisröl. Megadjuk minden teszt esetében a standard hibát is, a hozamok átlag körüli szórásának becsléseként, ebből következtethetünk arra, hogy a hozamok átlaga mennyire jó becslés a várható hozamra. A 95 százalékos konfidenciaintervallumot is megadjuk, így részletes képet kaphatunk arról, hogy milyen értékek között lesz várhatóan az adott részportfólió, illetve a likviditásnyújtás havi hozama.

Az 1. táblázat tartalmazza az egyenlően súlyozott tercilisportfóliók és a likviditásnyújtás esetén is a várható havi hozamot, a 0-tól való eltérés tesztjéhez tartozó NeweyWest-féle korrigált $t$-statisztika értékét és standard hibáját. Továbbá a havi hozamok 95 százalékos konfidenciaintervallumait is megadjuk.

\section{1. táblázat}

A likviditásnyújtás havi hozama tercilisportfóliók esetében, 1997. február-2019. január

\begin{tabular}{lccccc}
\hline Tercilis & $\begin{array}{c}\text { Várható hozam } \\
\text { (százalék) }\end{array}$ & Standard hiba & $t$-érték & \multicolumn{2}{c}{$\begin{array}{c}\text { 95 százalékos } \\
\text { konfidenciaintervallum (százalék) }\end{array}$} \\
\hline 1. & 1,65 & 0,0052 & 3,16 & 0,62 & 2,67 \\
2. & 1,05 & 0,0041 & 2,54 & 0,24 & 1,87 \\
3. & 1,32 & 0,0099 & 1,33 & $-0,63$ & 3,27 \\
$1-3$. & 0,33 & 0,0099 & 0,33 & $-1,62$ & 2,28 \\
\hline
\end{tabular}

Először a részportfóliók havi hozamára vonatkozó teszteket értékeljük. Érdekes, hogy minden részportfólió esetében pozitív a várható havi hozam, és az 1. és a 2. tercilis esetében a konfidenciaintervallum végpontjai is pozitívak. Ennek magyarázata az lehet, hogy olyan hosszú távon, mint amilyent vizsgálunk a tanulmányunkban, növekedés jellemzi a világ részvénypiacait, így a Budapesti Értéktőzsdét is. A standard hibák mindhárom esetben alacsonyak, tehát a hozamok átlaga mindhárom esetben jó becslést ad a várható hozamra.

További érdekesség, hogy az előző hónapban legrosszabbul teljesítő részvényeket tartalmazó portfólió várható havi hozama a legmagasabb, a portfólió hozama 5 százalékos szinten szignifikánsan eltér 0 -tól a $t$-érték alapján, és a konfidenciaintervallum mindkét végpontja pozitív. Ez az eredmény a stratégia hozamaival kapcsolatban is biztató.

A 2. részportfólió várható hozama szintén pozitív, a hozam a $t$-érték alapján 5 százalékos szinten szignifikánsan tér el 0 -tól, és a konfidenciaintervallum mindkét 
végpontja pozitív. Ugyanakkor a várható hozam és a konfidenciaintervallum végpontjai alacsonyak, a konfidenciaintervallum igen szük. Ez alapján ebbe a portfólióba nagyrészt átlagosan teljesítő részvények tartoznak, ezek 0-tól szignifikánsan eltérő, ugyanakkor nem túlzottan magas hozamúak.

A 3. részportfólió várható hozama is pozitív, ugyanakkor a hozam a t-érték alapján 5 százalékos szignifikanciaszinten nem tér el 0 -tól, és a konfidenciaintervallum bal végpontja negatív. A konfidenciaintervallum az előzőkhez képest tágabb, a standard hiba is ebben az esetben a legmagasabb. Ebbe a portfólióba az elöző hónapban legjobban teljesítő részvények tartoznak. A kapott eredmény szerint ezek között a részvények között vannak olyanok, amelyek továbbra is jól teljesítenek, de vannak olyanok is, amelyek visszahúznak az átlaghoz. Ez stratégiánk szempontjából már nem annyira kedvező. Abból, hogy a 3. részportfólió várható havi hozama is pozitív, arra következtethetünk, hogy a magasabb hozamok esetén kevésbé jellemző az átlaghoz való visszahúzás, mint a szélsőségesen rossz hozamok esetén.

A részportfóliókra vonatkozó tesztek után már rátérhetünk a stratégiánk hozamának tesztjére. Itt a $t$-érték alapján láthatjuk, hogy a nullhipotézist 5 százalékos szignifikanciaszinten nem tudjuk elvetni, vagyis a likviditásnyújtás hozama nem tér el szignifikánsan 0-tól. A standard hiba alacsony, tehát a hozamok átlaga jó becslés a várható havi hozamra. Azt is láthatjuk, hogy a 95 százalékos konfidenciaintervallum bal végpontja negatív, a jobb végpontja pedig pozitív, és egy eléggé szük intervallumról beszélünk az alacsony standard hibával összhangban. Ez is azt mutatja, hogy a hozam nem tér el szignifikánsan 0 -tól. Tehát a stratégia ilyen alkalmazásából nem számíthatunk szignifikánsan pozitív hozamra. Ugyanakkor a várható hozam pozitív, és a konfidenciaintervallum pozitív végpontja lényegesen nagyobb, mint a negatív végpont abszolút értéke, így a valóságban a likviditásnyújtás ilyen jellegü alkalmazásával a legtöbb esetben 0 -hoz közeli pozitív hozamot fogunk elérni.

\section{Az időzítés hatása a likviditásnyújtás várható hozamára}

A bevezetésben már tárgyaltuk, hogy a likviditásnyújtás akkor eredményezhet magasabb hozamokat, ha a befektetők gazdasági várakozásai pesszimisták, ugyanis ekkor számíthatunk likviditásszűkére. Válságok idején azért csökken a likviditás a legtöbb eszköz piacán, mert a befektetők kockázatvállalási hajlandósága csökken, pénzzé akarják tenni kockázatos eszközeiket, ugyanakkor nem találnak elég befektetőt, aki hajlandó lenne átvállalni a kockázatot, így a kereskedés volumene csökken, akár be is fagyhat a piac. Ezzel kapcsolatban két fö magyarázat létezik.

Gorton-Metrick [2010] szerint a kedvezötlen piaci sokkok nagymértékben növelik az értékpapírok új információkra való érzékenységét, a piacok egyre volatilisebbé válnak. A befektetők egyre nehezebben döntik el, hogy mibe fektessék be a pénzüket, ezért kevesebb pénzt fektetnek be, szélsőséges esetben csak készpénzben tartják vagyonukat. Így mivel egyre kisebb volumenben hajlandók a gazdaság szereplöi befektetni, a piacok likviditása lecsökken. E nézet szerint a likviditáshiány fö oka a bizonytalanság. 
Nagel [2012] szerint pénzügyi válságok esetén lecsökken a piaci szereplök likviditásnyújtó képessége, a piacon kielégítetlen likviditáskereslet marad. A kockázatosabbnak ítélt eszközök piacán a befektetők jellemzően eladni, a biztonságosnak tartott, „menekülö” eszközök piacán viszont jellemzően venni akarnak. Mivel azonban a befektetők többsége így tesz, az ügyletekhez egyre nehezebb lesz partnert találni, likviditáshiány alakul ki. Ha egy befektetőnek mégis sikerül számára megfelelö ügyleteket kötnie, akkor könnyen lehet, hogy egy időre beszünteti a kereskedést. Így a potenciális kereskedési partnerek is egyre fogynak. Az esetlegesen a piacon tevékenykedő árjegyző vagy az ehhez hasonló szereplők likviditásnyújtó képessége romlik, nem képesek megfelelő mértékben kielégíteni a piacok likviditásigényét, ők sem lesznek képesek kiegyensúlyozni a piacot. Ennek egyik oka lehet a többi piaci szereplő megnövekedett likviditáskereslete, a másik ok lehet az, hogy a pénzügyi problémák az árjegyzők, illetve a korábbi likviditásnyújtók egy részét is elérik, csökkenteniük kell a likviditásnyújtásra fordított pénzösszegeket. Ebben az esetben tehát valóban van a piacokon kielégítetlen likviditáskereslet, így ha egy piaci szereplő ebben a helyzetben képes többletlikviditást nyújtani, akkor szinte biztosan pozitív hozamokra számíthat. Tehát azzal, hogy azt keressük, mikor érhetünk el pozitív hozamokat a stratégiával, lényegében azt keressük, hogy a piacokon lévő befektetők vagy esetlegesen az árjegyzők mikor nem elégítik ki teljes mértékben a piacok likviditásigényét, mikor marad a piacokon kielégítetlen likviditáskereslet. Ez pedig pesszimista befektetői várakozások esetén a legvalószínübb az eddigiek alapján.

Tehát az ilyen pesszimistább hangulatban nehezebb, drágább és kockázatosabb likviditást nyújtani, ezért magasabb az elvárt hozam is a likviditást nyújtók szempontjából. Ezért alakulhat ki egy tartósan magasabb várható hozam a stratégia szempontjából. Itt a kockázat nem egyértelmüen a stratégia hozamának szórása, hanem emellett lehet még a tágabb ajánlati könyvből fakadó költségek kockázata vagy annak a kockázata, hogy a kívántnál sokkal tovább kell tartani egy adott pozíciót.

Ez alapján a három mutató segítségével azt vizsgáljuk meg, hogy milyen a likviditásnyújtás hozama optimista, illetve pesszimista befektetői várakozások esetében. Azt várjuk, hogy pesszimista várakozások esetében szignifikánsan pozitív hozamokat kapunk. A befektetői várakozásokat jellemző mutatók értékei az adatok szürése után szintén 1997 januárjától 2018 decemberéig állnak rendelkezésünkre.

A GKI konjunktúraindexe és a VIX index esetében nincs olyan elöre meghatározott küszöbérték, amely alapján eldönthetnénk, hogy optimisták vagy pesszimisták-e az adott havi várakozások. Ezért a mutatók vizsgált időszaki egyszerü számtani átlagát fogjuk küszöbértéknek használni. A VIX index esetében a legtöbben a 20-as érték alatt tekintik a piaci hangulatot bizakodónak, e fölött a befektetők aggódni kezdenek, a 30 és 100 közötti értékek már pánikot jeleznek. Ezek a határok azonban befektetőnként változhatnak, ezért inkább saját küszöbértéket használunk. A GKI mutatója és a CCI esetében akkor optimistábbak a várakozások, ha az indikátorok értéke nagyobb, a VIX index esetében viszont akkor, ha a mutató értéke kisebb, ezt figyelembe kell venni.

Hogy teljesebb képet kaphassunk a mutatók lehetséges értékeiről, volatilitásáról, a küszöbértékek mellett a 2. táblázatban megadjuk a mutatók minimális és maximális 
értékét, a mutatók szórását, továbbá azt, hogy az egyes mutatók szerint hány peszszimista, illetve optimista hónap volt a vizsgált időszakban a kijelölt küszöbértékek alapján. Semleges várakozásokat jelentő érték egyszer sem fordult elö.

\section{2. táblázat}

A mutatók küszöbértékei és egyéb jellemzői,1997. január-2018. december

\begin{tabular}{lccrccc}
\hline Mutató & $\begin{array}{c}\text { Küszöb- } \\
\text { értékek }\end{array}$ & & & & $\begin{array}{c}\text { A pesszimista } \\
\text { hónapok } \\
\text { száma }\end{array}$ & $\begin{array}{c}\text { Az optimista } \\
\text { hónapok } \\
\text { száma }\end{array}$ \\
\hline GKI konjunktúraindex & $-9,89$ & $-45,8$ & 10,46 & 10,16 & 120 & 144 \\
Euróövezeti CCI & 100 & 97,39 & 101,72 & 1,04 & 134 & 130 \\
VIX index & 20,39 & 9,51 & 59,89 & 7,88 & 148 & 116 \\
\hline
\end{tabular}

A CCI esetében kis szórást láthatunk, a maximális és a minimális érték igen közel van egymáshoz, a mutatóra kis nagyságrendű változások jellemzők. A VIX index szórása már jóval nagyobb, erre a mutatóra sokkal nagyobb kilengések jellemzők. A szórás a GKI mutatója esetén a legnagyobb, ez a legvolatilisebb mutató. Azzal, hogy minden mutató esetében megadjuk, hogy a mutató szerint a vizsgált időszakban a befektetői, fogyasztói várakozások hányszor voltak pesszimisták, illetve optimisták, képet kaphatunk arról, hogy az egyes mutatók szerint hogyan alakultak a befektetői, fogyasztói várakozások a vizsgált időszakban. Továbbá arról is meggyőződhetünk, hogy minden mutató esetében van elég megfigyelésünk ahhoz, hogy az optimista és a pesszimista várakozásokat elkülönítve teszteljük abból a szempontból, hogy a stratégia várható havi hozama szignifikánsan eltér-e 0 -tól. A mutatók értékeinek alakulása igen változatos. Éppen semleges gazdasági várakozások egy esetben sem voltak. A legtöbbször a VIX index jelez pesszimista várakozásokat, e mutató esetében egyértelműen túlsúlyban vannak a pesszimista értékek. Ez annak fényében nem meglepő, hogy a VIX közvetlen tőzsdei várakozásokat számszerüsít, a tőzsde pedig hajlamos túlreagálni a híreket. A pénzügyi intézmények és a befektetők folyamatosan elemzik a híreket, így több pesszimizmusra okot adó tényezőt tudnak azonosítani. Még az euróövezet CCI-je esetében is több a pesszimizmust jelző érték, a GKI konjunktúraindexe viszont jóval több optimizmust jelez. Tehát a magyarországi várakozások optimistábbak voltak, mint az euróövezetiek. Ennek magyarázata lehet, hogy az euróövezetben több szuverén válság is volt a vizsgált időszakban.

Fontos megjegyeznünk, hogy az optimizmust és pesszimizmust megragadó mutatókhoz mindig a portfóliókészítés hónapjára vonatkozó adatot használjuk fel. Tehát ez a kereskedési stratégia elméletben megvalósítható volt, mivel minden információ rendelkezésre állt az adott pillanatban. Ez egyértelműen igaz a VIX értékére és a GKI-mutatóra is. A CCI mutató esetében lehetséges, hogy az adatot csak késleltetve lehetett elérni.

A teszteknél most is 5 százalékos szignifikanciaszinten döntünk, és most is a Newey-West-féle $t$-statisztikát használjuk. Továbbra is minden esetben az a nullhipotézis, hogy a hozam 0 . A 3. táblázatban az eddigiekhez hasonlóan minden 
teszt esetében a várható hozamot, a standard hibát, a $t$-értéket és a 95 százalékos konfidenciaintervallumot mutatjuk be.

\section{3. táblázat}

A likviditásnyújtás havi hozama tercilisportfóliók esetében, időzítéssel, 1997. február-2019. január

\begin{tabular}{llccrcc}
\hline Mutató & Várakozások & $\begin{array}{c}\text { Várható } \\
\text { hozam } \\
\text { (százalék) }\end{array}$ & $\begin{array}{c}\text { Standard } \\
\text { hiba }\end{array}$ & t-érték & $\begin{array}{c}95 \text { százalékos } \\
\text { konfidenciaintervallum } \\
\text { (százalék) }\end{array}$ \\
\hline GKI & optimista & $-0,27$ & 0,0164 & $-0,17$ & $-3,51$ & 2,96 \\
konjunktúraindex & pesszimista & 1,05 & 0,0065 & 1,62 & $-0,23$ & 2,34 \\
Euróövezeti CCI & optimista & $-0,95$ & 0,0184 & $-0,52$ & $-4,58$ & 2,68 \\
& pesszimista & 1,57 & 0,0064 & 2,47 & 0,31 & 2,83 \\
VIX index & optimista & $-1,20$ & 0,0143 & $-0,84$ & $-4,03$ & 1,62 \\
& pesszimista & 2,29 & 0,0091 & 2,51 & 0,48 & 4,09 \\
\hline
\end{tabular}

Mindhárom vizsgált mutató a szakirodalom alapján várt eredményt adja: a $t$-érték alapján a hozam nagyobb mértékben eltér 0 -tól negatív befektetői várakozások esetében, mint pozitív befektetői várakozásokéban, és a várható hozam is minden vizsgált mutató esetében negatív várakozásoknál magasabb. Optimista befektetői várakozásoknál egyszer sem tér el a stratégia hozama szignifikánsan 0 -tól. Az is megfigyelhetö, hogy negatív várakozásoknál igen alacsonyak a standard hibák, ekkor minden mutató standard hibája alacsonyabb. Tehát negatív befektetői várakozásoknál a hozamok átlaga (negatív várakozások esetében vett átlag) a várható havi hozamnak igen jó becslése.

Ugyanakkor a GKI konjunktúraindexének pesszimista jelzéseinél a hozam nem tér el szignifikánsan 0-tól, még ha a konfidenciaintervallum viszonylag kedvező is. Ez magyarázható a külföldi befektetők jelentős túlsúlyával a magyar részvénypiacon, illetve a magyar lakosság befektetési szokásaival is. A magyar lakosság befektetési szokások szempontjából igen konzervatív más országok lakosságához képest, jelentős része vagy be sem fekteti a pénzét, vagy pedig a részvényeknél kevésbé kockázatos értékpapírokat választ, például magyar állampapírt. A külföldre vonatkozó két mutató pesszimista jelzéseinél a hozam a $t$-érték alapján szignifikánsan eltér 0 -tól 5 százalékos szignifikanciaszinten. Ez összhangban van a külföldi befektetők rendkívül magas arányával. Negatív várakozásoknál mindkét mutató esetében a konfidenciaintervallum mindkét végpontja pozitív, ami igen kedvező a stratégiát alkalmazó befektetők számára.

A két mutató közül a VIX index pesszimista jelzései adnak kedvezőbb értékeket, a várható hozam magasabb, a konfidenciaintervallum is kedvezőbb, és ha csak kicsivel is, de a $t$-érték is nagyobb. A VIX index közvetlenül az Amerika (sokak szerint az egész világ) értékpapírpiacain uralkodó félelmet, bizonytalanságot jellemzi. Így nem meglepő, hogy a mutató pesszimista értékeiből ilyen egyértelmüen megkapjuk a várt eredményt. Ugyanakkor az euróövezeti CCI értékei is kedvezők, így az az 
előzetes feltevésünk is helyesnek tűnik, hogy az euróövezetből származó befektetők jelentősen hatnak a BÉT-re.

Ezek alapján a likviditásnyújtás hozamai valóban együtt mozognak a befektetői várakozásokat jellemző mutatókkal, és valóban negatív várakozásoknál számíthatunk pozitív hozamokra. Az persze kérdéses, hogy a különböző várakozásokat számszerüsítő mutatók mennyire mozognak együtt, viszont erre nem kell válaszolnunk ahhoz, hogy elöre jelezzük a kereskedési stratégia hozamait, elegendő a mutatók és a stratégia hozamának kapcsolatát vizsgálnunk. Probléma lehet viszont, hogy a várható hozamok igen alacsonyak, a maximális várható hozam is csak 2,29 százalék, a konfidenciaintervallum-végpontok maximális értéke pedig csak 4,09 százalék. Ez a tőzsdei kereskedés járulékos költségeivel együtt (például fedezet fenntartása, tranzakciós díjak) már nem biztos, hogy megéri, ennél magasabb hozamokat kellene elérni.

\section{Alternatív portfólióképzés}

A likviditásnyújtás hozamait megpróbálhatjuk úgy javítani, hogy az eddiginél több részportfóliót alakítunk ki az előző havi hozamok alapján. Ekkor az eddiginél nagyobb mértékben alulteljesítő, alacsonyabb árú részvényeket veszünk meg, és szélsőségesebben felülteljesítő, magasabb árú részvényeket adunk el, vagy shortolunk. A szélsőségesebb teljesítményeknél az átlaghoz való visszahúzás, a korrekció mértéke is nagyobb lehet, ez kedvező a stratégia hozamaira nézve. E változtatás az alapján is megfelelö lehet, hogy a szélsőséges alul- vagy felülteljesítések gyakran rövid távú sokkok eredményei, a kiugró teljesítmények után gyakran gyorsan bekövetkezik az átlaghoz való visszahúzás.

Ugyanakkor ne tegyük túl szélsőségessé a stratégiát azzal, hogy túl sok részre osztjuk a részvényeket! Ekkor ugyanis igen kevés értékpapírba fogunk ténylegesen befektetni, portfóliónk nagyon rosszul diverzifikált lesz, föleg a magyar piacon, amelyen nemzetközi összehasonlításban kevés részvény van. Ezek alapján végül a decilisrészportfóliók mellett döntöttünk, ez egy gyakran használt felosztás egyváltozós sorba rendezés esetében. Ekkor a legalacsonyabb 10 százalék kerül az alsó decilisbe, a legmagasabb 10 százalék a felső decilisbe, a további deciliseket is értelemszerüen alakítjuk ki, a 10 százalék és 20 százalék közötti rész kerül a 2. decilisbe, a 20 százalék és 30 százalék közötti rész kerül a 3. decilisbe, és így tovább. Továbbra is egyenlően súlyozott portfóliókat modellezünk.

Ekkor a likviditásnyújtási stratégia meghatározása szerint az 1. részportfóliót vesszük meg, és a 10. részportfóliót adjuk el, így az 1. portfólió havi hozamaiból kivonva a 10. portfólió havi hozamait kapjuk a likviditásnyújtás havi hozamait. Ezután ugyanúgy, mint az előző felosztásnál, a Newey-West-féle $t$-statisztikával teszteljük, hogy a részportfóliók, illetve a stratégia havi hozama szignifikánsan eltér-e 0 -tól. Továbbra is 5 százalékos szignifikanciaszinten döntünk, és a várható hozamot, a standard hibát, a $t$-értéket és a 95 százalékos konfidenciaintervallumot jelenítjük meg minden teszt esetén (4. táblázat). 
4. táblázat

A likviditásnyújtás havi hozama decilisportfóliók esetén, 1997. február-2019. január

\begin{tabular}{cccccc}
\hline Decilis & $\begin{array}{c}\text { Várható hozam } \\
\text { (százalék) }\end{array}$ & $\begin{array}{c}\text { Standard } \\
\text { hiba }\end{array}$ & $t$-érték & \multicolumn{2}{c}{95 százalékos } \\
konfidenciaintervallum (százalék)
\end{tabular}

Elöször e felosztásnál is a részportfóliókra vonatkozó teszteket értékeljük. Az eredmények az előző felosztáshoz hasonlóan alakulnak. A várható hozam az 1. decilishez tartozó részportfólió, vagyis az előző hónapban legrosszabbul teljesítő részvényeket tartalmazó portfólió esetén a legmagasabb. A hozam is ekkor tér el a legszignifikánsabban 0 -tól a $t$-érték alapján, és a konfidenciaintervallum is ekkor a legkedvezőbb. A 1. decilisportfólió várható havi hozama jóval magasabb, mint az előző esetben az 1. tercilisportfólió várható havi hozama - ez biztató a likviditásnyújtás várható hozamaira nézve. Ezek a megállapítások alátámasztják azt a korábbi feltevésünket, hogy a szélsőségesen rossz hozamok okai gyakran nem a hosszú távú problémák, hanem a rövid távú sokkok. Továbbá az is megerösítést nyer, hogy a magyar részvénypiacon jellemző az átlaghoz való visszahúzás, legalábbis a szélsőségesen rossz teljesítményeket követően. A standard hiba a többi portfólióhoz képest viszonylag magas, ez alapján a realizált hozamok jobban fognak ingadozni az átlag körül, mint a többi portfólió esetében. A viszonylag tág konfidenciaintervallum is összhangban van ezzel.

A hozamok a 2. decilis esetében is szignifikánsan eltérnek 0-tól a portfólióhoz tartozó $t$-érték alapján (sőt ez 1 százalékos szignifikanciaszinten is teljesül), a várható hozam ekkor is pozitív, sőt a konfidenciaintervallum végpontjai is pozitívak, bár e részportfóliónál a várható hozam jóval alacsonyabb, mint az 1. részportfólió esetében, és a konfidenciaintervallum is jóval kedvezőtlenebb. Ez alapján ebben a portfólióban is többségben vannak azok a részvények, amelyek csak rövid távú sokk miatt teljesítettek rosszul, bár itt már az elöző portfóliónál nagyobb számban lehetnek olyan részvények is, amelyek hosszabb távon is rosszul teljesítenek. Az eredmény az alapján is logikus, hogy ezek a részvények az előző portfólió elemeinél kisebb mértékben maradtak el az átlagos teljesítménytöl, így a korrekció mértéke is kisebb. A standard hiba e portfólió esetében már igen alacsony, itt a hozamok átlaga igen jó becslés a várható havi hozamra. 
A 3. részportfólió hozama nem tér el szignifikánsan 0-tól, bár a várható hozam negatív. A portfólió standard hibája igen alacsony, tehát a hozamok átlaga jó becslése a várható havi hozamnak. Ezek alapján ebbe a portfólióba kerül a legtöbb olyan részvény, amely hosszú távon is veszteséges. Ez az eredmény is összhangban van azzal, hogy a legrosszabb hozamok nem feltétlenül a hosszú távon is rosszul teljesítő részvényekhez tartoznak, a legszélsőségesebb negatív hozamok gyakran csak rövid távú sokkok eredményei.

A 4. és az 5. portfólió esetében a várható hozam pozitív, azonban a hozam nem tér el szignifikánsan 0-tól, bár a t-értékek viszonylag közel vannak az ilyen elemszámú mintára vonatkozó küszöbértékhez. A standard hiba mindkét portfóliónál alacsony, a hozamok átlaga mindkét esetben jó becslést nyújt a várható havi hozamra, ezzel összhangban a konfidenciaintervallumok is szükek. A konfidenciaintervallumok bal végpontja negatív e portfólióknál, viszont a bal végpontok abszolút értéke jóval kisebb, mint a pozitív jobb végpontok értéke. Ez alapján e portfóliókba többségében olyan részvények kerülnek, amelyek hosszú távon pozitív, de nem túl nagy hozammal rendelkeznek. Mivel hosszú távon általában a növekedés jellemző a részvényárfolyamokra, valószínüleg e portfóliókat nagyrészt átlagosan teljesítő részvények alkotják.

A 6. portfólió hozama nem tér el szignifikánsan 0-tól, ugyanakkor a várható hozam itt is pozitív, bár a 3. portfólió után ennek a portfóliónak a várható hozama a legkisebb. Ez alapján ebben a portfólióban nagyjából hasonló mennyiségben vannak hosszú távon nyereséges, illetve veszteséges részvények, és hosszú távon stagnáló részvények is nagy számban lehetnek a portfólióban. A standard hiba e portfólió esetében is kicsi.

A 7. portfólió hozama szignifikánsan eltér 0-tól, a várható hozam pozitív, és a konfidenciaintervallum végpontjai is pozitívak. Ugyanakkor a portfólióra jellemzö hozamok nem túl nagyok, a várható hozam is jóval alacsonyabb, mint az 1. részportfólió esetén, és a konfidenciaintervallum is jóval kedvezőtlenebb. Ez alapján ebbe a portfólióba nagyrészt hosszabb távon is jól teljesítő, viszont alacsony hozamú részvények tartoznak. A standard hiba e portfólió esetében a legalacsonyabb, ez alapján is igen biztosan hozza a portfólió a pozitív havi hozamot. Ebből arra is következtethetünk, hogy hasonlóan a rosszul teljesítő részvényekhez és a negatív hozamokhoz, a legnagyobb pozitív hozamok sem feltétlenül a hosszú távon is jól teljesítő részvényekhez tartoznak.

A 8. portfólió esetében a várható havi hozam a t-érték alapján nem tér el szignifikánsan 0-tól. A várható hozam itt is pozitív, illetve a konfidenciaintervallum is egészen kedvező, bár a bal végpont negatív, a jobb végpont egy - a bal végpont abszolút értékénél jóval nagyobb - pozitív szám. Ez alapján ebben a portfólióban is többségében vannak a hosszabb távon is jól teljesítő részvények, bár valószínüleg minden hónapban lesznek a portfólióban olyan részvények is, amelyek visszahúznak az átlaghoz. A standard hiba e portfólió esetében is viszonylag alacsony.

A 9. és 10. portfóliók, vagyis az előző hónap legjobban teljesítő részvényeit tartalmazó portfóliók hozamai nem térnek el szignifikánsan 0-tól, ugyanakkor a portfóliók várható hozamai most is pozitívak. Az viszont látszik, hogy a 9. portfólióban több a hosszabb távon is jól teljesítő részvény, a portfólió várható hozama jóval magasabb, 
mint a 10. portfólióé, és a konfidenciaintervallum is kedvezőbb a 9. portfólió esetében. A standard hiba mindkét esetben magasabb, mint az eddigi részportfóliók többségénél, egyedül az 1. részportfóliónál volt hasonló érték. A 10. részportfólió esetében a legmagasabb a standard hiba, várhatóan e portfólióban lesznek a legingadozóbbak a jövőbeli hozamok. Ez alapján a szélsőségesen jól teljesítő részvényeknél gyakoribb az átlaghoz való visszahúzás, mint a piacot kisebb mértékben felülmúló részvényeknél, viszont ez az átlaghoz való visszahúzás még mindig nem olyan gyakori, mint a szélsőségesen alulteljesítő részvények esetében. Az, hogy a 10. portfólió várható hozama pozitív, kedvezőtlen a likviditásnyújtás szempontjából.

Ezután rátérünk a likviditásnyújtás havi hozamának vizsgálatára. Ugyan a hozam itt sem tér el szignifikánsan 0-tól, de a $t$-érték már sokkal közelebb van a küszöbértékhez, mint a tercilisekre bontással kapott portfólió esetében. A várható hozam pozitív, illetve a konfidenciaintervallum bal végpontja ugyan negatív, de a jobb végpont sokkal nagyobb, mint a bal végpont abszolút értéke. Ez alapján, ha ezt a stratégiát követjük, pozitív hozamra számíthatunk, ami nem tér el szignifikánsan 0-tól, ugyanakkor sokkal magasabb, mint az előző esetben. Ezzel összhangban a konfidenciaintervallum is egyértelműen kedvezőbb, mint a tercilis-részportfóliók esetében. A standard hiba jóval magasabb, mint a terciliseknél, a jövőbeli hozamok szórása várhatóan nagyobb lesz, mint az elöző esetben. Ez összhangban van az eddigieknél jóval tágabb konfidenciaintervallummal. Tehát a stratégia szélsőségesebbé tétele jó elgondolásnak bizonyul. Ennek magyarázata lehet, hogy a szélsőségesen jól, illetve rosszul teljesítő részvények piacán magasabb a likviditás iránti kereslet, a rosszul teljesítő részvényeket nehezebb eladni, a szélsőségesen jól teljesítő részvényeket pedig kevesen hajlandók eladni. Helyesnek bizonyul az a feltételezésünk is, hogy a szélsőséges hozamokat gyakran követi gyors átlaghoz való visszahúzás, ez különösen igaz a kiemelkedően rossz hozamok esetében.

\section{Az időzítés hatása a decilisportfólió képzésénél}

Az eddigi három mutatót használva vizsgáljuk meg a stratégia e változatát is külön a pozitív és külön a negatív befektetői várakozásokra! Arra számítunk, hogy a fent leírtak szerinti decilisportfóliók képzésével a tercilisek képzésénél kedvezőbb hozamokat és szignifikánsabb, robusztusabb eredményeket kapunk. A három mutató pesszimizmust, illetve optimizmust jelző értékeire vonatkozó tesztek nullhipotézise most is az, hogy a várható havi hozam szignifikánsan eltér-e 0 -tól, a Newey-West-féle korrigált $t$-statisztikát használjuk, és most is 5 százalékos szignifikanciaszinten döntünk. Az 5. táblázatban az eddigiekhez hasonlóan a várható havi hozamot, a standard hibát, a t-értéket és a 95 százalékos konfidenciaintervallumot mutatjuk be minden tesztre.

A stratégia e változatában még jobban látszik a hozamok és a gazdasági szereplök várakozásainak együttmozgása, konkrétabban az, hogy negatív várakozásoknál számíthatunk pozitív hozamokra. Ebben az esetben egyetlen mutató optimizmust jelző értékeinél sem szignifikáns a hozam. Viszont mindhárom mutató pesszimizmust jelző értékeinél szignifikánsan pozitív a hozam. A várható hozamok is sokkal 


\section{5. táblázat}

A likviditásnyújtás havi hozama decilisportfóliók esetén, időzítéssel, 1997. február-2019. január

\begin{tabular}{llcccrc}
\hline Mutató & Várakozások & $\begin{array}{c}\text { Várható } \\
\text { hozam } \\
\text { (százalék) }\end{array}$ & $\begin{array}{c}\text { Standard } \\
\text { hiba }\end{array}$ & $t$-érték & $\begin{array}{c}\text { 95 százalékos } \\
\text { konfidenciaintervallum } \\
\text { (százalék) }\end{array}$ \\
\hline GKI & optimista & 2,66 & 0,0324 & 0,82 & $-3,74$ & 9,07 \\
konjunktúraindex & pesszimista & 3,91 & 0,0152 & 2,57 & 0,90 & 6,92 \\
\hline Euróövezeti CCI & optimista & 0,90 & 0,0340 & 0,26 & $-5,83$ & 7,62 \\
& pesszimista & 5,49 & 0,0182 & 3,02 & 1,89 & 9,09 \\
\hline VIX index & optimista & 0,54 & 0,0267 & 0,20 & $-4,73$ & 5,81 \\
& pesszimista & 6,66 & 0,0230 & 2,90 & 2,11 & 11,21 \\
\hline
\end{tabular}

magasabbak a negatív várakozások esetében, mint amikor tercilis-részportfóliókból alakítottuk ki a vizsgált portfóliót (lásd a 3. táblázatot). Az eredmények annak a várakozásunknak is megfelelnek, hogy robusztusabbak: a negatív várakozások esetén kapott $t$-értékek minden esetben magasabbak, mint amekkorák tercilisrészportfóliók esetében voltak. A standard hibák is nagyobbak, s itt már ingadozóbbak a hozamok. Az eddigieknél tágabb konfidenciaintervallumok is megfelelnek a magasabb standard hibáknak. Ugyanakkor azt most is megkaptuk, hogy a standard hibák pesszimista várakozások esetén alacsonyabbak, ilyenkor a hozamok átlaga jobb becslést ad a várható havi hozamra.

A három mutató közül továbbra is a GKI konjunktúraindexének előrejelző képessége a leggyengébb, ez továbbra is a külföldi befektetők magas arányával, a magyar lakosság befektetési szokásaival magyarázható. Az euróövezet CCI-je és a VIX index - a külföldi befektetők magas arányának megfelelően - pesszimista értékei esetében már igen robusztus eredményeket kapunk, a várható hozam 1 százalékos szinten is szignifikánsan pozitív. A mutatók pesszimista értékei esetén kapott várható hozamok és konfidenciaintervallumok már egyértelmüen vonzók lehetnek a befektetők számára. Olyan szempontból továbbra is a VIX index előrejelző képessége a legjobb, hogy ennél a mutatónál kapjuk a legmagasabb várható hozamot, és a konfidenciaintervallum is kedvezőbb, mint az euróövezet CCI-jénél. Ugyanakkor a $t$-érték az euróövezet CCI-jénél magasabb, a szignifikánsan pozitív hozam e mutató esetében robusztusabb eredmény. Ennek magyarázata lehet, hogy az euróövezeti CCI standard hibája jóval alacsonyabb, kevésbé ingadozik a hozam a várható hozam körül, így a 0 -tól való eltérés is biztosabb, szignifikánsabb.

Az eredmények hasonlósága a tercilisek képzéséhez egyáltalán nem meglepő, hiszen a két stratégia elméleti háttere pontosan ugyanaz, csak a második eset egy szélsőségesebb megközelítés. Ezek alapján azt kapjuk, hogy a likviditásnyújtás portfólióképzésen alapuló megközelítésével elérhető pozitív hozam, és minél jobban alulteljesítő részvényeket veszünk és felülteljesítő részvényeket adunk el, annál magasabb a várható hozam. A stratégia hozama együtt mozog a gazdasági várakozásokat 
jellemző mutatókkal, pesszimista várakozások esetén számíthatunk pozitív hozamra. Az eredmények igazolják, hogy a magyar részvénypiacon jellemző az átlaghoz való visszahúzás, leginkább a szélsőségesen rossz hozamok után.

\section{Likviditásnyújtás a teljes piacra}

Ezután vizsgáljuk meg a likviditásnyújtás egy más megközelítését. Ezt a konkrét befektetési stratégiát Lehmann [1990] vizsgálta elöször, de ezt a megközelítést használta Nagel [2012], illetve Hameed-Mian [2015] is. Most minden, az adott tözsdén lévő részvénybe befektetünk egy adott súllyal, minden részvény piacán likviditást nyújtunk. Ezért ez a megközelítés különösen hasznos lehet akkor, ha az a célunk, hogy minél több értékpapír piacán nyújtsunk likviditást.

Ebben az értelmezésben eladjuk az előző havi piaci átlaghozamot felülteljesítő részvényeket, és megvesszük azokat, amelyek a piaci átlaghoz képest alulteljesítettek. Ahhoz, hogy meg tudjuk határozni, hogy mely részvényeket adjuk el, és melyeket vegyük meg, kiszámítjuk minden hónapra az átlaghozamot. Ha egy részvény nagyobb mértékben teljesít alul, akkor a korrekció mértéke is nagyobb lehet, ez alapján érdemes nagyobb súllyal vennünk az inkább alulteljesítő részvényekből. Ez a likviditásnyújtással is összhangban van, a nagyobb mértékben alulteljesítő részvényekből valószínüleg többet akarnak eladni, így az ilyen piacokon a likviditásszüke is nagyobb lehet, ezért nagyobb hozamot várhatunk az általunk nyújtott likviditásért. Hasonlóan, az átlagot nagyobb mértékben felülmúló részvényeket érdemes lehet nagyobb súllyal eladnunk vagy shortolnunk, szintén a várhatóan nagyobb korrekció és likviditáshiány miatt. Tehát a befektetési súlyokat érdemes megfeleltetnünk az alul-, illetve felülteljesítés mértékének. A súlyok felírásához vezessünk be néhány jelölést. $\mathrm{Az} i$-edik részvény $t$-edik időszaki súlyát jelöljük $w_{i t}$-vel, az $i$-edik részvény $t$-edik idöszaki hozamát jelölje $R_{i t}$. A hozamok $t$-edik időszaki egyszerủ számtani átlagát jelöljük $R_{m t}$-vel. Az adott havi részvények számát jelöljük $N$-nel. A $t$-edik idöszaki súlyokat a $(t-1)$-edik időszaki hozamok alapján határozzuk meg:

$w_{i t}=-\frac{R_{i t-1}-R_{m t-1}}{\frac{1}{2}\left(\sum_{i=1}^{N}\left|R_{i t-1}-R_{m t-1}\right|\right)}$.

Ezek a súlyok az előzetes elvárásainknak megfelelnek, hiszen ha a részvény felülteljesíti a piaci átlagot, akkor $R_{i t-1}>R_{m t-1}$, így $R_{i t-1}-R_{m t-1}>0$, a szumma az abszolút értékek miatt biztosan pozitív, így a súly negatív lesz, tehát ezt a részvényt eladni, vagy ha nem birtokoljuk, akkor shortolni fogjuk. Ha viszont $R_{i t-1}<R_{m t-1}$, akkor $R_{i t-1}-R_{m t-1}<0$, a súly pozitív lesz, ezeket a részvényeket valóban venni fogjuk. Az is teljesül, hogy a súlyok megfelelnek az alul-, illetve felülteljesítés többi részvényhez viszonyított mértékének, hiszen a súlyok abszolút értékeit úgy kapjuk, hogy az adott részvény hozamának átlagtól vett abszolút eltérését elosztjuk minden részvény hozamának átlagtól vett abszolút eltérésének összegével, és ezt a hányadost megszorozzuk kettővel, amit úgy is tekinthetünk, hogy a nevezőt szorozzuk meg 1/2-del. 
Ezt azért tesszük, hogy az eladott és vett részvények súlyainak összege külön-külön 1 legyen. Ez azért hasznos, mert így könnyebb végrehajtani a stratégiát a gyakorlatban. Mivel egy portfólió hozama az elemek hozamainak súlyozott átlaga, a teljes portfólió hozama, amit $R$-rel jelölünk:

$R=-\frac{\sum_{i=1}^{N}\left(R_{i t-1}-R_{m t-1}\right) R_{i t}}{\frac{1}{2}\left(\sum_{i=1}^{N}\left|R_{i t-1}-R_{m t-1}\right|\right)}$.

A súlyokat kiszámítjuk az (1) szerint minden hónapra, majd kiszámítjuk a portfólió havi hozamait a (2) alapján. Ezeket az adatokat felhasználva fogjuk tesztelni, hogy a stratégiánk havi hozama szignifikánsan eltér-e nullától. Mivel az adott havi portfólió összetételének megállapításához most is szükségünk van előző havi hozamokra, az előző esethez hasonlóan 1997 februárjától 2019 januárjáig tudjuk tesztelni a stratégia hozamait az 1997 januárja és 2018 decembere közötti hozamok alapján. Először a teljes időszakra időzítés nélkül vizsgáljuk, hogy a stratégia havi hozama szignifikánsan eltér-e 0-tól, majd pedig az eddig is használt három mutató segítségével külön optimista és pesszimista befektetői várakozásokra is - Newey-West-féle $t$-statisztikával elvégezzük a teszteket. Az sem változik, hogy 5 százalékos szignifikanciaszinten döntünk, és hogy minden tesztre bemutatjuk a várható havi hozamot, a standard hibát, a $t$-értéket, valamint a 95 százalékos konfidenciaintervallumot.

\section{6. táblázat}

A teljes piacra vonatkozó likviditásnyújtás havi hozama a teljes időszakra, illetve időzítéssel, 1997. február-2019. január

\begin{tabular}{llccrrr}
\hline Mutató & Várakozások & $\begin{array}{c}\text { Várható } \\
\text { hozam } \\
\text { (százalék) }\end{array}$ & $\begin{array}{c}\text { Standard } \\
\text { hiba }\end{array}$ & $t$-érték & \multicolumn{2}{c}{$\begin{array}{c}95 \text { százalékos } \\
\text { konfidenciaintervallum } \\
\text { (százalék) }\end{array}$} \\
\hline Teljes időszak & & 2,69 & 0,0176 & 1,53 & $-0,77$ & 6,15 \\
\hline GKI & optimista & 1,53 & 0,0285 & 0,54 & $-4,11$ & 7,17 \\
konjunktúraindex & pesszimista & 4,08 & 0,0114 & 3,59 & 1,83 & 6,33 \\
Euróövezeti CCI & optimista & 0,09 & 0,0306 & 0,03 & $-5,97$ & 6,15 \\
& pesszimista & 5,21 & 0,0140 & 3,71 & 2,43 & 7,98 \\
VIX index & optimista & 0,65 & 0,0261 & 0,25 & $-4,51$ & 5,81 \\
& pesszimista & 5,29 & 0,0172 & 3,07 & 1,88 & 8,70 \\
\hline
\end{tabular}

A teljes időszakra vonatkozó teszt $t$-értéke alapján a hozam nem tér el szignifikánsan 0 -tól, de több várt eredményt is megkapunk. A várható hozam pozitív, illetve a konfidenciaintervallum bal végpontja ugyan negatív, de a jobb végpont sokkal nagyobb, mint a bal végpont abszolút értéke. Tehát pozitív hozamra számíthatunk, ami nem tér el szignifikánsan 0-tól, de magasabb, mint amikor tercilisrészportfóliókkal, viszont alacsonyabb, mint amikor decilis-részportfóliókkal alakítottuk ki a stratégiát. A konfidenciaintervallum értékei is az előző két stratégia értékei között vannak. Ennek magyarázata lehet, hogy ez a stratégia a súlyok használatával 
pontosan figyelembe veszi, hogy a részvény milyen mértékben teljesített alul vagy felül, viszont minden részvénybe befektet, nem alakít ki olyan speciális portfóliót, mint a decilisekre osztást alkalmazó stratégia.

Az időzítéssel kapott havi hozamok tesztjeinek eredményei hasonlítanak a decilisekre osztással kialakított stratégia eredményeihez. Optimista várakozásoknál most sem kapunk egyetlen esetben sem szignifikáns hozamot. Viszont negatív várakozásoknál az eddigi legrobusztusabb eredményeket kapjuk, minden mutató pesszimizmust jelző értékei esetében magasabb a $t$-érték, mint a két portfólióképzésen alapuló értelmezés esetén, a várható hozamok már 1 százalékos szinten is szignifikánsan pozitívak minden indikátor esetében. Ennek magyarázata lehet, hogy ezzel a stratégiával minden részvénybe befektetünk, minden lehetséges kielégítetlen likviditási igényt kihasználunk.

Továbbra is a GKI konjunktúraindexének előrejelző képessége a legkevésbé jó abból a szempontból, hogy a várható hozam és a konfidenciaintervallum ennél a mutatónál a legkedvezőtlenebb, bár az értékek közeledtek a többi mutató értékeihez az előző stratégiákhoz képest. A konjunktúraindex pesszimista jelzései mellett a teljes piacra vonatkozó értelmezés esetében kapjuk az eddigi legmagasabb várható hozamot. A GKI mutatójára kapott $t$-érték pedig már magasabb, mint a VIX indexre kapott $t$-érték. Ennek magyarázata lehet, hogy a VIX index esetében jóval magasabb a standard hiba, ingadozóbb a hozam. A legmagasabb várható hozamot továbbra is a VIX index esetében kapjuk, ugyanakkor a mutató pesszimista értékeihez tartozó konfidenciaintervallum már nem kedvezőbb egyértelműen, mint az euróövezeti CCI esetében kapott konfidenciaintervallum. Ennek magyarázata megint a VIX index pesszimista értékeinél kapott magas standard hiba lehet. Ennek ellenére a VIX index pesszimista értékeire minden értelmezésben szignifikánsan pozitív hozamot, sőt a legmagasabb várható hozamot kapjuk, így a VIX index jó előrejelző képessége igen erős eredmény. Ebben az értelmezésben az eu róövezet CCI-je esetén kapjuk a legmagasabb $t$-értéket, a pozitív várható hozam nagyon robusztus eredménynek tekinthetö. A várható hozam, ha csak kevéssel is, de alacsonyabb, mint a VIX index esetében, de ahogy már említettük, a konfidenciaintervallum nem kedvezőtlenebb egyértelmüen. Az euróövezeti CCI pesszimista értékeire is minden értelmezésben szignifikánsan pozitív hozamot kapunk, kedvező várható hozammal és konfidenciaintervallummal, tehát ez az indikátor jó elörejelző képessége is erös eredmény.

A maximális várható hozam és a legkedvezőbb konfidenciaintervallum valamivel rosszabb, mint amilyen a decilis-részportfóliókat alkalmazó értelmezésnél volt, de ez a kevésbé speciális portfólió miatt nem meglepö. Tehát a likviditásnyújtás ilyen értelmezése mellett is azt kapjuk, hogy megfelelő időzítéssel érhetünk el szignifikánsan pozitív hozamot. A stratégia hozamai a befektetői várakozásokat jellemző mutatókkal ebben az értelmezésben is együtt mozognak. A kapott eredmények megerősítik, hogy a magyar részvénypiacra jellemző az átlaghoz való viszszahúzás, elsősorban pesszimista befektetői várakozások esetében. Ez továbbra is azzal magyarázható, hogy pesszimista, kiszámíthatatlanabb hangulatban magasabb hozamot várhatunk a likviditásnyújtásért. 


\section{Összefoglalás}

Azt kaptuk, hogy mindkét - a portfólióképzésre, illetve a teljes piacra vonatkozó megközelítéssel szignifikánsan pozitív hozam érhetö el. Eszerint a Budapesti Értéktőzsdén jegyzett részvények árfolyamaira és hozamaira jellemző az átlaghoz való visszahúzás. Különösen az első megközelítés második változatánál figyelhető meg jól, hogy ez az átlaghoz való visszahúzás leginkább szélsőségesen alacsony hozamok után jellemző. A hozam mindkét megközelítésben együtt mozog a gazdasági várakozásokat jellemző mutatókkal, pesszimista várakozások esetén szignifikánsan pozitív hozamot érhetünk el. Ez alapján a Budapesti Értéktőzsdén is igaz az, hogy az átlaghoz való visszahúzásra építő stratégiák pozitív hozama azért marad fenn, mert ez a likviditást nyújtó befektetők nyeresége, ugyanis a likviditásnyújtás kockázata lényegesen magasabb pesszimista, kiszámíthatatlanabb gazdasági környezetben. A vizsgált mutatók közül a VIX index és az euróövezeti CCI alapján történő időzítéssel minden értelmezésben szignifikánsan pozitív várható hozamot kapunk, e mutatók jó elörejelző képessége igen erős eredmény. A GKI konjunktúraindexe csak a szélsőségesebb portfólióképzés és a teljes piacra vonatkozó megközelítés esetében rendelkezik jó elörejelző képességgel. Ez a mutató gyengébb előrejelző képessége azzal magyarázható, hogy a BÉT-en igen magas a külföldi befektetők aránya. Hozamok szempontjából a legjobb előrejelző képessége a VIX indexnek van, ez alapján kereskedve a portfólióképzéssel 6,66 százalék, a teljes piacra vonatkozó megközelítéssel 5,29 százalék a várható havi hozam. Ezek alapján egy profitmaximalizáló befektetőnek az első megközelítés második változata javasolt, hiszen a várható hozam ekkor magasabb. Viszont ha a likviditásnyújtás a cél, akkor a teljes piacra vonatkozó megközelítés is rendkívül hasznos lehet, hiszen ezzel egy elöre kijelölt portfólió minden elemébe be tudunk fektetni úgy, hogy portfóliónk várható hozama pozitív legyen. Tehát az eredmények amellett, hogy befektetőként profitot érhetünk el a leírtak alapján, arra is alkalmasak lehetnek, hogy a piacon lévő likviditás mennyiségét jövedelmezően növeljük, és így a kereskedés minőségét is javítsuk.

\section{Hivatkozások}

Annaert, J.-De Ceuster, M.-Verstegen, K. [2013]: Are extreme returns priced in the stock market? European evidence. Journal of Banking \& Finance, Vol. 37. No. 9. 3401-3411. o. https://doi.org/10.1016/j.jbankfin.2013.05.015.

Chan, W. S. [2003]: Stock price reaction to news and no-news: drift and reversal after headlines. Journal of Financial Economics, Vol. 70. No. 2. 223-260. o. https://doi.org/10.1016/ s0304-405x(03)00146-6.

Cheon, Y. H.-LeE, K. H. [2017]: Maxing out globally: Individualism, investor attention, and the cross section of expected stock returns. Management Science, Vol. 64. No. 12. 5807-5831. o. https://doi.org/10.1287/mnsc.2017.2830.

Cochrane, J. H. [1999]: New facts in finance. NBER Working Paper, No. w7169. National Bureau of Economic Research, https://doi.org/10.3386/w7169. 
Csávás Csaba-Erhart SzIlárd [2005]: Likvidek-e a magyar pénzügyi piacok? A devizaés állampapír-piaci likviditás elméletben és gyakorlatban. MNB tanulmányok, 44. https:// www.mnb.hu/letoltes/mt-44.pdf.

Csillag BALÁzs-Neszveda GÁbor [2020]: A gazdasági várakozások hatása a tőzsdei momentumstratégiára. Közgazdasági Szemle, 7. évf. 11. sz. 1093-1111. o. https://doi. org/10.18414/ksz.2020.11.1093.

FAMA, E. F. [1991]: Efficient capital markets: II. Journal of Finance, Vol. 46. No. 5 1575-1617. o. https://doi.org/10.1111/j.1540-6261.1991.tb04636.x.

FAma, E. F.-French, K. R. [1992]: The Cross-Section of Expected Stock Returns. Journal of Finance, Vol. 47. No. 2. 427-465. o. https://doi.org/10.1111/j.1540-6261.1992.tb04398.x.

Gorton, G.-Metrick, A. [2010]: Haircuts. Federal Reserve Bank of St. Louis Review, Vol. 92. 507-520. o. https://doi.org/10.20955/r.92.507-20.

Hameed, A.-Mian, G. M. [2015]: Industries and stock return reversals. Journal of Financial and Quantitative Analysis, Vol. 50. No. 1-2. 89-117. o. https://doi.org/10.1017/ s0022109014000404.

Hendershott, T.-Jones, C. M.-Menkveld, A. J. [2011]: Does Algorithmic Trading Improve Liquidity? Journal of Finance, Vol. 66. 1-33. o. https://doi.org/10.1111/j.15406261.2010.01624.x.

Hevér Judit [2017]: A likviditás és a permanens árhatás szerepe a portfólióértékelésben. Közgazdasági Szemle, 64. évf. 6. sz. 594-611. o. https://doi.org/10.18414/ksz.2017.6.594.

KANIEL, R.-SAAR, G.-TITMAN, S. [2007]: Individual investor trading and stock returns. Journal of Finance, Vol. 63. No. 1. 273-310. o. https://doi.org/10.1111/j.1540-6261.2008.01316.x.

Lehmann, B. N. [1990]: Fads, martingales, and market efficiency. The Quarterly Journal of Economics, Vol. 105. No. 1. 1-28. o. https://doi.org/10.2307/2937816.

Mérő Balázs-Nagy Olivér-Neszveda Gábor [2019]: Új faktorok tesztelése az empirikus eszközárazásban. Szigma, 50. évf. 4. sz. 263-281. o.

Nagel, S. [2012]: Evaporating liquidity. The Review of Financial Studies, Vol. 25. No. 7. 2005-2039. o. https://doi.org/10.1093/rfs/hhs066.

Nartea, G. V.-Kong, D.-Wu, J. [2017]: Do extreme returns matter in emerging markets? Evidence from the Chinese stock market. Journal of Banking \& Finance, Vol. 76. 189-197. o. https://doi.org/10.1016/j.jbankfin.2016.12.008.

Newey, W.-West, K. D. [1987]: A Simple, Positive Semi-Definite, Heteroskedasticity and Autocorrelation Consistent Covariance Matrix. Econometrica, Vol. 55. No. 3. 703-708. o. https://doi.org/10.2307/1913610.

Shumway, T. [1997]: The delisting bias in CRSP data. Journal of Finance, Vol. 52. No. 1. 327340. o. https://doi.org/10.1111/j.1540-6261.1997.tb03818.x.

VÁRADI KATA [2012]: Likviditási kockázat a részvénypiacokon. PhD-tézisek, BCE Gazdálkodástani Doktori Iskola. 